\title{
The influence of different thinning methods on dominance coefficients of future crop trees in even-aged Scots pine stands
}

\author{
Tadeusz Zachara \\ Forest Research Institute, Department of Silviculture and Genetics, Sękocin Stary, ul. Braci Leśnej 3, 05-090 Raszyn, Poland. \\ Tel. +48 22 7150686; e-mail T.Zachara@ibles.waw.pl
}

\begin{abstract}
The research aim was to evaluate the influence of different thinning methods on future crop tree growth.
Investigations were conducted on permanent Scots-pine experimental plots, established in 1960s and 1970s in Kozienice, Łąck, Parciaki and Janów Lubelski Forest Districts. To assess the response to thinning of future crop trees, their dominance coefficients were used. These are defined as quotients for each given future crop tree diameter and average stand diameter (WP1), the average dominant layer diameter (WP2) and the average diameter of 100 thickest trees per hectare (WP3). The difference between each coefficient value at the beginning and at the end of the measurement period was used as a measure of the thinning effect.

On Kozienice, Łąck and Parciaki plots the differences between treatments were significant, especially in the period after first thinning. The increase of WP3 coefficient occurred in a case of strong thinning - TS1 and TS2. On plot Parciaki also the moderate thinning TU1 and TU2 had a significant influence on change of this coefficient. On plot Janów Lubelski the influence of treatment has not been stated in the first 5-year period but in the next one.

Analyses of changes in the dominance coefficients confirmed the hypothesis that the WP3 coefficient is very useful as it is the most stable indicator of future crop-tree position in a stand. On Kozienice, Łąck and Parciaki plots the significant differences between treatments were stated, especially in the period after first thinning.

The influence of thinning treatment on the plot Janów Lubelski was not considered for the first 5-year period but in the next one. All reactions to thinning were slower on this plot, possibly because of the relatively poor site conditions.

This was a long-term effect.

The results obtained suggest that very intense thinning of Scots pine stands should only be implemented under a restricted set of conditions - in healthy, not neglected, forest stands. Classical moderately-selective thinning is preferable to intense thinning and is the most convenient option for pine stands.
\end{abstract}

Key words: Scots pine, permanent experimental plots, dominance coefficients, thinning intensity

\section{Introduction and study aim}

There are two essential approaches to breeding selection in European thinning concept. The classical approach consists of the use during forest stand tending the phenomenon of natural competition and comes down to moderate interference in this process to help individuals of desirable quality features in the competitive strug- gle (Schädelin 1942; Leibundgut 1972; Zajączkowski 1994). In practice, it means a multi-phase selection of best forest stands components, with cooperation of nature forces and human decisions.

The second approach, more modern, consists of transferring the burden of selection to humans and minimising competition between trees. The result of this approach is an early selection of crop trees, strong cut- 
ting and maintenance of open canopy in forest stands (Abetz 1967; Johann 1981; Huss 1983, 1993). One of the essential causes of such an approach change is an increase of forest work costs, resulting in simplification of interventions and their mechanisation.

Except quality formation, an important factor taken into consideration during thinning planning is a forest stand's stability, including inter alia its resistance to mechanical damages caused by atmospheric factors, especially wind and snow, and particularly in case of coniferous species forest stands (Konôpka et al. 1987; Zajączkowski 1991; Peltola et al. 2000). With reference to this, two approaches can be distinguished - first, focusing on tree's individual resistance (Fries 1969; Abetz 1976; Johann 1981; Huss 1983, 1993, Stępień 1986; Konôpka et al. 1987) and, second, emphasising the importance of group immunity (Zajączkowski 1990, 1994; Slodičak 1995; Peltola et al. 1993; Talkkari et al. 2000). The first approach leans towards loose spacing and strong thinning and slenderness coefficient is considered to be a basic stability measurer, which is a relation of diameter breast height (dbh) to height $\mathrm{h} / \mathrm{d}$. The second approach prefers moderate cutting, not breaking permanently canopy density (light and moderate thinning, possibly group thinning). The compromise model involves the use of the first strategy at young age (to II class) and a gradual decrease of cutting intensity in average age and older forest stands (Slodičak 1995).

Due to an expected increase of renewable energy in general consumption, the interest in wood use for energy purposes is renewed (Alam et al. 2012). It may result in using again denser spacing and more frequent thinning (Routa et al. 2011).

Thinning research in Forestry Research Institute has a long history and in a large measure based on results from permanent experimental plots (Bernadzki 1969; Grynkiewicz 1972, 1988; Ilmurzyński 1974; Zachara 1998, 1999, 2000). On the basis of research conducted on permanent experimental plots in pine forest stands of II age class in Wyszków, Ostrów Mazowiecka and Myszyniec Forest Inspectorate, a positive influence of selective thinning on growth of crop tree population was stated, if the intensity of first cutting amounted to no less than $20 \%$. A distinct influence was noticeable with cutting intensity amounting to $30 \%$. In this research, for selective thinning effect evaluation, measurers among others called 'dominance coefficients' (Zachara 1998, 1999) based on the relation between dbh of examined tree and average dbh of whole forest stand or defined trees class were used. Among the examined coefficients, the best coefficient of thinning effect was WP3 coefficient, defined as ratio of crop tree's dbh to average dbh of 100 thickest trees per hectare.

The aim of study was to define the influence of various thinning methods on growth of forest stand and population of chosen crop trees. In particular, it needs to be stated what dominance in increase in thickness individual thinning types provide and how permanent this effect is.

\section{Research methodology}

\subsection{Research objects}

The research was conducted on the following permanent experimental plots of the Forestry Research Institute:

- Kozienice Forest Inspectorate, Forest District Chinów, comp. 100

- Łąck Forest Inspectorate, Forest District Korzeń, comp. 286b, 290 b, g

- Parciaki Forest Inspectorate, Forest District Bramura, comp 149

- Janów Lubelski Forest Inspectorate, Forest District Bukowa, comp. 192, 218, 219.

The first three mentioned objects were created as spacing areas, and from 1999 they were treated as thinning areas. A plot in Janów Lubelski was created as thinning area in an already existing small polewood stage.

Kozienice, Łąck and Parciaki plots were created by planting after soil preparation by full cultivation. The planting material was 1-year-old Scots pine seedlings.

Plot in Kozienice Forest Inspectorate was created in an area of fresh coniferous forest, I site index in 1965. Plot dimensions were $16 \times 36 \mathrm{~m}$. Plot in Forest Inspectorate Łąck was created in 1965 in an area of fresh coniferous forest, II site index. Dimensions of whole plots were $40 \times 40 \mathrm{~m}$, while measuring plots were $21 \times 37 \mathrm{~m}$. Plot in Parciaki Forest Inspectorate was created in 1966 in an area of fresh coniferous forest, I site index, on former agricultural land. Dimensions of whole plots were $50 \times 50 \mathrm{~m}$, and measuring plots were $49 \times 17 \mathrm{~m}$.

Forest stand to 35-year-olds in Parciaki plot did not undergo any tending interventions; in Łąck and Kozienice plots run was moderate early thinning (Ląck -25 years, Kozienice -30 years).

Thinning experiment began in 1999-2001 in these plots. Thinning experiment in Kozienice plot includes four repetitions, in Parciaki and Łąck plots three repetitions, whereas Łąck plot had no correct block system.

In each repetition, the following experiment treatments occurred: 
$\mathrm{K}$ - control (without thinning) in forest stand grown from cultivation planted in rectangular spacing $1.2 \times 0.8 \mathrm{~m}$; TU1 - classic selective thinning (moderate) in forest stand grown from cultivation planted in square sparing (distance between seedlings $1.0 \mathrm{~m}$ );

TU2 - classic selective thinning (moderate) in forest stand grown from cultivation planted in triangular spacing (distance between seedlings $1.2 \mathrm{~m}$ );

TS1 - heavy thinning by crop trees in forest stand grown from cultivation planted in square spacing (distance between seedlings $1.2 \mathrm{~m}$ );

TS2 - heavy thinning by crop trees in forest stand grown from cultivation planted in rectangular spacing $1.2 \times 0.55 \mathrm{~m}$;

TG1 - group thinning in forest stand grown from cultivation planted in square spacing (distance between seedlings $0.8 \mathrm{~m}$ );

TG2 - group thinning in forest stand grown from cultivation planted in triangular spacing (distance between seedlings $1.0 \mathrm{~m}$ ).

On surfaces designed were crop trees, according to adopted below assumptions, and around them

- harmful trees, for removal. Crop trees were marked in a permanent way, with a band painted by aerosol. The method of designing crop trees and trees from removal was as follows:

- at classic thinning (treatments TU1 and TU2) 500 crop trees per hectare were chosen, maintaining the regularity of their arrangement. From harmful trees group, no more than one tree from dominant layer was removed;

- at group thinning (treatments TG1 and TG2), crop trees in the same number as previously were chosen, without maintaining the criteria of even space. During thinning, removal of good quality dominant trees was attempted to be avoided;

- at heavy thinning (treatments TS1 and TS2) crop trees in number of 350 trees per hectare were chosen, arranged as far as possible regularly. From their direct neighbourhood, all competitors in contact with their crowns were removed.

Thinning according to above assumptions in Kozienice plots was planned in 1999, and in Łąck and Parciaki plots in 2000. Another thinning in Kozienice Forest Inspectorate was planned in 2007 and in Ląck Forest Inspectorate in 2008. In Parciaki plot, due to strong biotic damages, only sanitary cuttings were performed from 2003.

Janów Lubelski plot was created in 1976, in 21-yearold Scots pine of I site index (II in places) in an area of fresh coniferous forest. Experiment was started in a system of three random blocks for testing the influence of linear cutting and selective thinning of various intensifications on stability and productivity of forest stands in II age class. In this plot, the following cuttings treatments were used:

$\mathrm{K}$ - control;

$\mathrm{S} 1$ - light selective thinning, with basal area reduction by $10 \%$ in relation to control treatment;

S3 - heavy selection thinning, with basal area reduction by $30 \%$;

TE - extreme thinning - in first cutting over $60 \%$ of basal area was removed.

Size of each plot was 0.1 ha. Last thinning on this plot was planned in 2008 .

\subsection{Measurements on experimental plots}

Forest stand in Kozienice, Łąck and Parciaki plots was measured before the beginning of experiment (in 19971999). Following measurements in Kozienice plot took place in 2005 and 2011; Łąck in 2003, 2007 and 2012; and Parciaki in 2003, 2006 and 2012. Measurements on Janów Lubelski plot was performed every 5 years between 1976 and 2001, and then in 2007 and 2012.

In Kozienice, Łąck and Parciaki plots, dbh measurements were performed (in two directions) with an accuracy of $1 \mathrm{~mm}$, and total height measurements and height of all living crown base treatment (with an accuracy of $0.1 \mathrm{~m}$ ). Tree's location in experimental plots was accurately defined. A silvicultural quality classification of individual trees according to Schädelin scale was conducted (Bernadzki et al. 1999).

In Janów Lubelski plot, dbh of all trees were measured and their classification was made, whereas the height was measured of around 30 trees in every plot in order to calculate the regression between $\mathrm{dbh}$ and height (height curve).

\subsection{Elaboration of results}

Measurement results are presented as tables and graphs. In tables, the number of trees and dbh basal area, average dbh, height and upper height and dbh of 100 thickest trees per hectare were presented, from the beginning of thinning experiment and the last measurement.

Dominance coefficients of crop trees were defined in the following way:

$$
\begin{aligned}
& \mathrm{WP} 1=d_{d} / D, \\
& \mathrm{WP} 2=d_{i} D_{A}, \\
& \mathrm{WP} 3=d_{i} / D_{g},
\end{aligned}
$$


where $d_{i}-$ dbh of a given tree, $D$ - average dbh of whole forest stand, $D_{A}$ - average dbh of dominant trees class ( $1^{\text {st }}$ social class in Schädelin classification, which corresponds to I and II class in Kraft's scale) and $D_{g}$ dbh of 100 thickest trees per hectare. Values $D, D_{A}$ and $D_{g}$ were treated as permanent within individual plots.

Average dominance coefficients for individual plots of experiment are presented in tables.

The results underwent two-factor variance analysis. As a variability source taken was experiment treatment, group of trees (distinguishing thick, average and thin trees) and interactions between them. The differences between averages were compared with Tukey test.

For statistical analysis Statistica 8 package was used.

For statistical calculations, a group of trees of aligned initial parameters was chosen. Only crop trees were chosen in which WP3 coefficient in the beginning of research was included in the range $0.65-0.95$, rejecting the thinnest and thickest individuals. In each variant chosen were 30 trees, 10 from each range: $0.65-0.75$, $0.75-0.85$ and $0.85-0.95$. In total, 210 trees in each of Kozienice, Łąck and Parciaki plots were chosen and 120 trees in Janów plot.

Changes of WP3 coefficient were analysed, which are differences between coefficient value of given tree in the end and beginning of each measurement period. For Kozienice plot, coefficient differences in 1999-2011 were moreover calculated, for Łąck plot coefficient differences in 1997-2012, and for Parciaki plot differences in 1998-2012. That is, between a measurement made before the beginning of thinning experiment and the last measurement. The year of measurement, not on every plot coincided with the beginning of experiment or performing the cutting. For plots like Janów, such longterm changes were calculated for three periods, i.e. from the beginning of experiment in 1976 to:

- 1981, after first thinning,

- 1996 (approximately this period corresponded to II age class),

-2012 , that is, to the last measurement.

\section{Research results}

\subsection{Biometric features in different cutting treatments}

In Kozienice plot (Table 1), the initial number of trees ranged from 2849 individuals/ha (treatment TS1) to 3537 individuals/ha (treatment TG1), and basal area from $29.739 \mathrm{~m}^{2} /$ ha (TS2) to $33.398 \mathrm{~m}^{2} /$ ha (TS1). Treat- ment TS1 was characterised by higher dbh value, both average and upper. During last measurement, the number of trees was from 1132 individuals/ha in treatment TS1 (heavy thinning) to 2076 individuals/ha in treatment $\mathrm{K}$ (control), and forest stand basal area from $24.412 \mathrm{~m}^{2} / \mathrm{ha}$ in treatment TS2 to $34.804 \mathrm{~m}^{2} / \mathrm{ha}$ in control treatment. Differences were a consequence of cutting performed according to the plan. Relatively low values of basal area are a result of occurrence of snow and wind damages in winter months in 2009-2010. These damages did not have a whole-surface character, but a single-tree character, and so they did not disrupt the experiment.

In Łąck plot (Table 2), the number of initial trees ranged from 3004 individuals/ha in treatment TS1 to 4312 individuals/ha in treatment TG1. Initially, basal area was the smallest in control treatment $\left(27.767 \mathrm{~m}^{2} / \mathrm{ha}\right)$, and the biggest in treatment TS2 (30.916 m²/ha). During last measurement, the number of trees ranged from 1300 individuals/ ha in treatment TS1 to 2064 individuals/ha in control treatment. Forest stands basal area was estimated from 26.234 $\mathrm{m}^{2} /$ ha in treatment TS1 to $34.790 \mathrm{~m}^{2} /$ ha in control treatment. Sporadic abiotic damages (wind, snow) and biotic damages (Phaenops cyanea) did not have a significant influence on course of experiment. In the results (as in Kozienice), internal habitat diversity has some influence, expressed in forest stand's upper height diversity.

In Parciaki plot (Table 3) at the beginning of thinning experiment, tree density was much higher than on earlier plots discussed (compare Section 2.1), as is evidenced by tree number from 3896 individuals/ha in treatment TU2 to 5117 individuals/ha in treatment TG1, and basal area from $35.738 \mathrm{~m}^{2} /$ ha in control treatment to $39.382 \mathrm{~m}^{2} / \mathrm{ha}$ in treatment TS1. After the beginning of experiment, biotic damages intensified, causing widening of existing gap and formation of new ones. That is why part of the plots during last measurement was characterised by extremely small number of trees and basal area, despite the fact that after occurrence of damages the thinning was stopped and only sanitary cuttings were performed. Treatment TG2 was characterised by the biggest basal area $\left(30.237 \mathrm{~m}^{2} / \mathrm{ha}\right)$, that is, group thinning in forest stand planted in triangular spacing. The smallest basal area $\left(19.883 \mathrm{~m}^{2} / \mathrm{ha}\right)$ was in treatment TG1 (dense square sparing, group thinning).

In Janów Lubelski plot (Table 4) at the beginning of experiment, forest stand's basal area was similar in all treatments, while the number of trees was the highest in control treatments (6403 individuals/ha) and in S1 light thinning (5783 individuals/ha), which proves the diversity of certain objects. Measurement results from 1996 were disrupted on 
Table 1. Stand characteristics in experimental plot Kozienice

\begin{tabular}{|c|c|c|c|c|c|c|c|c|c|c|c|}
\hline \multirow{2}{*}{ Year } & \multirow{2}{*}{ Treatment* } & \multicolumn{6}{|c|}{ Total stand** } & \multicolumn{4}{|c|}{ Future crop trees } \\
\hline & & $n$ (pcs./ha) & $G\left(\mathrm{~m}^{2} / \mathrm{ha}\right)$ & $H(\mathrm{~m})$ & $D(\mathrm{~cm})$ & $H_{g}(\mathrm{~m})$ & $D_{g}(\mathrm{~cm})$ & $n$ (pcs./ha) & $G\left(\mathrm{~m}^{2} / \mathrm{ha}\right)$ & $H(\mathrm{~m})$ & $D(\mathrm{~cm})$ \\
\hline \multirow{8}{*}{1999} & $\mathrm{~K}$ & 3349 & 32.659 & 13.4 & 11.2 & 14.6 & 17.3 & 493 & 7.749 & 14.1 & 14.1 \\
\hline & TG1 & 3537 & 30.402 & 13.2 & 10.5 & 14.7 & 15.8 & 550 & 7.647 & 14.1 & 13.4 \\
\hline & TG2 & 3118 & 31.016 & 13.6 & 11.3 & 15.3 & 17.3 & 580 & 8.854 & 14.6 & 14.0 \\
\hline & TS1 & 2849 & 33.398 & 14.0 & 12.3 & 15.0 & 18.8 & 374 & 7.152 & 14.8 & 15.6 \\
\hline & TS2 & 3175 & 29.739 & 13.7 & 10.9 & 15.2 & 16.7 & 365 & 5.942 & 14.7 & 14.4 \\
\hline & TU1 & 3045 & 30.938 & 13.8 & 11.4 & 14.9 & 17.1 & 511 & 8.475 & 14.7 & 14.1 \\
\hline & TU2 & 3054 & 30.869 & 13.5 & 11.4 & 14.8 & 17.1 & 510 & 8.394 & 14.3 & 14.4 \\
\hline & average & 3161 & 31.288 & 13.6 & 11.3 & 14.9 & 17.1 & 483 & 7.745 & 14.5 & 14.3 \\
\hline \multirow{8}{*}{2011} & $\mathrm{~K}$ & 2076 & 34.804 & 16.0 & 14.7 & 17.3 & 21.5 & 459 & 11.072 & 16.6 & 17.6 \\
\hline & TG1 & 1595 & 28.245 & 16.1 & 15.0 & 17.4 & 21.0 & 523 & 12.132 & 16.6 & 17.0 \\
\hline & TG2 & 1495 & 30.031 & 16.8 & 16.0 & 18.0 & 21.8 & 550 & 13.819 & 17.3 & 17.9 \\
\hline & TS1 & 1132 & 26.738 & 16.6 & 17.5 & 17.3 & 22.8 & 369 & 11.870 & 17.2 & 20.2 \\
\hline & $\mathrm{TS} 2$ & 1302 & 24.412 & 16.4 & 15.5 & 17.3 & 21.2 & 357 & 9.692 & 16.9 & 18.6 \\
\hline & TU1 & 1364 & 27.599 & 16.8 & 16.1 & 17.8 & 22.6 & 491 & 13.511 & 17.3 & 18.7 \\
\hline & TU2 & 1382 & 26.836 & 16.4 & 15.8 & 17.5 & 21.7 & 505 & 13.181 & 16.9 & 18.2 \\
\hline & average & 1478 & 28.381 & 16.5 & 15.8 & 17.5 & 21.8 & 465 & 12.182 & 17.0 & 18.3 \\
\hline
\end{tabular}

* $\quad \mathrm{K}-$ control treatment (no thinning), initial spacing of plantation $1.2 \times 0.8 \mathrm{~m}$

TG1 - group thinning, initial spacing of plantation $0.8 \times 0.8 \mathrm{~m}$

TG2 - group thinning, initial spacing of plantation - triangle $1.0 \mathrm{~m}$

TS1 - strong thinning, initial spacing of plantation $-1.21 .2 \mathrm{~m}$

TS2 - strong thinning, initial spacing of plantation $1.2 \times 0.55 \mathrm{~m}$

TU1 - moderate thinning, initial spacing of plantation $1.0 \times 1.0 \mathrm{~m}$

TU2 - moderate thinning, initial spacing of plantation - triangle $1.2 \mathrm{~m}$

** $n$ - number of trees

$G$ - basal area

$H$ - mean height

$D$ - mean dbh

$H_{g}$ - top height

$D_{g}^{g}$ - mean dbh of 100 thickest trees per hectare

the other hand by cutting mistakenly performed by the then forest administration on some part of plot. As a result, basal area in control treatment was lower than in light thinning treatment. During the last measurement, the forest stand was characterised by tree number from 677 individuals/ ha in heavy thinning treatment (S3) to 1280 individuals/ ha in control treatment; on the other hand, forest stands basal area was the smallest in treatment S3 $\left(26.594 \mathrm{~m}^{2} / \mathrm{ha}\right)$, and the highest, according to expectations, in control treat- ment $\left(35.327 \mathrm{~m}^{2} / \mathrm{ha}\right)$. The lowest values of trees number and basal area, obtained in S3 treatment, result from the fact that in treatment of extreme thinning (TE) the cutting was performed more rarely than in remaining treatments. By comparing values of average dbh and height in individual treatments, it may be noticed that in heavy thinning treatments (S3 and TE) - unlike treatments control $(\mathrm{K})$ and light thinning (S1) - average slenderness dropped below the critical value of 100 . 
Table 2. Stand characteristics of experimental plot Łąck

\begin{tabular}{|c|c|c|c|c|c|c|c|c|c|c|c|}
\hline \multirow{2}{*}{ Year } & \multirow{2}{*}{ Treatment* } & \multicolumn{6}{|c|}{ Total stand } & \multicolumn{4}{|c|}{ Future crop trees } \\
\hline & & $n$ (pcs./ha) & $G\left(\mathrm{~m}^{2} / \mathrm{ha}\right)$ & $H(\mathrm{~m})$ & $D(\mathrm{~cm})$ & $H_{g}(\mathrm{~m})$ & $D_{g}(\mathrm{~cm})$ & $n$ (pcs./ha) & $G\left(\mathrm{~m}^{2} / \mathrm{ha}\right)$ & $H(\mathrm{~m})$ & $D(\mathrm{~cm})$ \\
\hline \multirow{8}{*}{1997} & $\mathrm{~K}$ & 3405 & 27.767 & 12.1 & 10.3 & 13.6 & 15.5 & 506 & 6.364 & 12.7 & 12.6 \\
\hline & TG1 & 4312 & 32.184 & 11.5 & 9.7 & 12.8 & 15.3 & 516 & 6.696 & 12.4 & 12.9 \\
\hline & TG2 & 3232 & 28.700 & 12.1 & 10.6 & 13.4 & 16.2 & 516 & 7.426 & 12.8 & 13.5 \\
\hline & TS1 & 3004 & 28.327 & 12.1 & 11.0 & 13.2 & 16.4 & 352 & 5.438 & 12.7 & 14.0 \\
\hline & TS2 & 4011 & 30.916 & 11.6 & 9.9 & 12.7 & 15.3 & 334 & 4.525 & 12.4 & 13.1 \\
\hline & TU1 & 3477 & 28.666 & 12.1 & 10.4 & 13.5 & 16.3 & 481 & 6.905 & 12.8 & 13.5 \\
\hline & TU2 & 3253 & 28.639 & 11.7 & 10.6 & 12.6 & 15.9 & 496 & 6.850 & 12.3 & 13.3 \\
\hline & average & 3528 & 29.314 & 11.9 & 10.4 & 13.1 & 15.8 & 457 & 6.315 & 12.6 & 13.3 \\
\hline \multirow{8}{*}{2012} & $\mathrm{~K}$ & 2064 & 34.790 & 17.3 & 14.9 & 18.2 & 22.0 & 477 & 11.509 & 17.5 & 17.5 \\
\hline & TG1 & 1827 & 30.391 & 15.9 & 14.6 & 16.8 & 19.2 & 515 & 11.911 & 16.6 & 17.2 \\
\hline & TG2 & 1595 & 31.145 & 17.1 & 15.9 & 18.2 & 22.8 & 504 & 13.695 & 17.7 & 18.6 \\
\hline & TS1 & 1300 & 26.234 & 16.7 & 16.1 & 17.8 & 23.0 & 334 & 10.095 & 17.3 & 19.6 \\
\hline & TS2 & 1537 & 26.874 & 16.1 & 14.9 & 17.6 & 21.7 & 330 & 9.170 & 16.9 & 18.8 \\
\hline & TU1 & 1449 & 28.207 & 16.7 & 15.6 & 18.4 & 22.3 & 440 & 11.369 & 17.3 & 18.2 \\
\hline & TU2 & 1567 & 27.781 & 15.9 & 15.1 & 17.0 & 21.6 & 482 & 12.155 & 16.5 & 17.9 \\
\hline & average & 1620 & 29.346 & 16.5 & 15.3 & 17.7 & 21.8 & 440 & 11.415 & 17.1 & 18.3 \\
\hline
\end{tabular}

* As in Table 1

Table 3. Stand characteristics in experimental plot Parciaki

\begin{tabular}{|c|c|c|c|c|c|c|c|c|c|c|c|}
\hline \multirow{2}{*}{ Year } & \multirow{2}{*}{ Treatment* } & \multicolumn{6}{|c|}{ Total stand } & \multicolumn{4}{|c|}{ Future crop trees } \\
\hline & & $n$ (pcs./ha) & $G\left(\mathrm{~m}^{2} / \mathrm{ha}\right)$ & $H(\mathrm{~m})$ & $D(\mathrm{~cm})$ & $H_{g}(\mathrm{~m})$ & $D_{g}(\mathrm{~cm})$ & $n$ (pcs./ha) & $G\left(\mathrm{~m}^{2} / \mathrm{ha}\right)$ & $H(\mathrm{~m})$ & $D(\mathrm{~cm})$ \\
\hline \multirow{8}{*}{1998} & $\mathrm{~K}$ & 4153 & 35.738 & 14.1 & 10.5 & 15.6 & 18.0 & 481 & 7.689 & 15.0 & 14.3 \\
\hline & TG1 & 5117 & 36.441 & 13.4 & 9.0 & 15.3 & 17.6 & 556 & 8.418 & 14.5 & 13.9 \\
\hline & TG2 & 4516 & 36.872 & 13.8 & 9.7 & 15.6 & 18.0 & 533 & 8.971 & 14.9 & 14.6 \\
\hline & TS1 & 3752 & 39.382 & 14.3 & 11.1 & 15.9 & 19.5 & 359 & 6.890 & 15.1 & 15.6 \\
\hline & $\mathrm{TS} 2$ & 4646 & 39.263 & 13.9 & 10.1 & 15.6 & 18.2 & 355 & 6.198 & 15.0 & 14.9 \\
\hline & TU1 & 4104 & 38.880 & 14.1 & 10.6 & 15.3 & 18.0 & 493 & 8.476 & 15.0 & 14.8 \\
\hline & TU2 & 3896 & 38.457 & 13.9 & 10.8 & 15.1 & 18.2 & 514 & 9.004 & 14.7 & 14.9 \\
\hline & average & 4312 & 37.862 & 13.9 & 10.3 & 15.5 & 18.2 & 470 & 7.949 & 14.9 & 14.7 \\
\hline \multirow{8}{*}{2012} & $\mathrm{~K}$ & 1295 & 26.537 & 18.0 & 16.3 & 19.3 & 23.2 & 316 & 8.299 & 18.7 & 18.5 \\
\hline & TG1 & 942 & 19.883 & 17.3 & 16.4 & 18.8 & 24.2 & 295 & 8.895 & 18.0 & 19.6 \\
\hline & TG2 & 1469 & 30.237 & 18.2 & 16.2 & 19.6 & 23.7 & 441 & 13.097 & 18.9 & 19.4 \\
\hline & TS1 & 881 & 21.967 & 18.0 & 17.9 & 19.3 & 24.5 & 225 & 7.968 & 18.6 & 21.2 \\
\hline & $\mathrm{TS} 2$ & 974 & 21.839 & 17.7 & 16.9 & 19.0 & 23.8 & 259 & 8.681 & 18.5 & 20.7 \\
\hline & TU1 & 1034 & 23.492 & 18.4 & 17.0 & 19.4 & 23.4 & 322 & 10.239 & 18.8 & 20.2 \\
\hline & TU2 & 1023 & 23.633 & 18.0 & 17.5 & 19.0 & 23.6 & 359 & 11.360 & 18.5 & 20.1 \\
\hline & average & 1088 & 23.941 & 17.9 & 16.9 & 19.2 & 23.8 & 317 & 9.791 & 18.6 & 20.0 \\
\hline
\end{tabular}

\footnotetext{
* As in Table 1
} 
Table 4. Stand characteristics in experimental plot Janów Lubelski

\begin{tabular}{|c|c|c|c|c|c|c|c|c|c|c|c|}
\hline \multirow{2}{*}{ Year } & \multirow{2}{*}{ Treatment* } & \multicolumn{6}{|c|}{ Total stand } & \multicolumn{4}{|c|}{ Future crop trees } \\
\hline & & $n$ (pcs./ha) & $G\left(\mathrm{~m}^{2} / \mathrm{ha}\right)$ & $H(\mathrm{~m})$ & $D(\mathrm{~cm})$ & $H_{g}(\mathrm{~m})$ & $D_{g}(\mathrm{~cm})$ & $n$ (pcs./ha) & $G\left(\mathrm{~m}^{2} / \mathrm{ha}\right)$ & $H(\mathrm{~m})$ & $D(\mathrm{~cm})$ \\
\hline \multirow{5}{*}{1976} & $\mathrm{~K}$ & 6403 & 27.473 & 9.4 & 7.4 & 11.5 & 12.9 & 757 & 6.220 & 10.6 & 10.4 \\
\hline & S1 & 5783 & 26.375 & 9.5 & 7.6 & 11.4 & 13.7 & 597 & 5.615 & 10.6 & 10.9 \\
\hline & $\mathrm{S} 3$ & 5093 & 27.634 & 10.2 & 8.3 & 11.9 & 14.3 & 640 & 6.559 & 11.1 & 11.4 \\
\hline & $\mathrm{TE}$ & 4873 & 27.961 & 10.2 & 8.6 & 11.8 & 15.0 & 600 & 6.598 & 11.0 & 11.8 \\
\hline & average & 5538 & 27.361 & 9.8 & 8.0 & 11.7 & 14.0 & 648 & 6.248 & 10.8 & 11.1 \\
\hline \multirow{5}{*}{1996} & $\mathrm{~K}$ & 1707 & 28.260 & 16.6 & 14.7 & 18.2 & 20.5 & 683 & 13.670 & 17.11 & 16.2 \\
\hline & S1 & 1820 & 30.564 & 16.6 & 14.8 & 17.9 & 21.6 & 570 & 12.756 & 17.11 & 16.8 \\
\hline & $\mathrm{S} 3$ & 1243 & 26.333 & 16.9 & 16.6 & 18.5 & 22.5 & 497 & 13.197 & 17.37 & 18.4 \\
\hline & TE & 953 & 26.746 & 17.8 & 18.9 & 18.9 & 24.7 & 537 & 16.804 & 18.06 & 20.0 \\
\hline & average & 1431 & 27.976 & 17.0 & 16.3 & 18.4 & 22.3 & 572 & 14.107 & 17.4 & 17.9 \\
\hline \multirow{5}{*}{2012} & $\mathrm{~K}$ & 1280 & 35.327 & 20.7 & 18.8 & 22.3 & 25.7 & 610 & 18.745 & 21.0 & 20.0 \\
\hline & S1 & 1030 & 31.006 & 19.9 & 19.6 & 21.3 & 26.7 & 420 & 14.982 & 20.3 & 21.2 \\
\hline & $\mathrm{S} 3$ & 677 & 26.594 & 21.8 & 22.5 & 23.1 & 28.5 & 373 & 16.574 & 22.1 & 23.9 \\
\hline & $\mathrm{TE}$ & 697 & 30.754 & 22.1 & 23.7 & 23.1 & 29.8 & 437 & 20.750 & 22.3 & 24.6 \\
\hline & average & 921 & 30.920 & 21.1 & 21.2 & 22.4 & 27.7 & 460 & 17.763 & 21.4 & 22.4 \\
\hline
\end{tabular}

* $\mathrm{K}$ - control treatment, without thinning

$\mathrm{S} 1$ - light thinning, $10 \%$ basal area reduction

S3 - strong thinning, 30\% basal area reduction

$\mathrm{TE}$ - very strong thinning, over $60 \%$ basal area reduction at the first cutting

** As in Table 1

\subsection{Advantage coefficients of crop trees and their changes}

\subsubsection{Kozienice plot}

In the beginning of experiment, the dominance coefficient of crop trees over the average of forest stand (WP1) was similar in all treatments. Only coefficient in treatment TS2 had a slightly higher value (Table 5). After 6 years (year 2005), there was a drop of dominance coefficient in majority of treatments, wherein the biggest decrease was in treatments TG1 and TG2, where the increase of average dbh was faster than the increase of crop trees dbh. The coefficient in treatment TS1 did not change where crop trees deprived of competition gained the possibility of growth due to exposure, and also in treatment $\mathrm{K}$ where increase of average dbh was small. After the next 6 years, the coefficient dropped in all treatments, which can be explained by the displacement (natural and due to thinning) of the thinnest trees from lower layers and the increase of average dbh connected with this process. In 2012, this coefficient had the highest value in treatment TS2.

Coefficient WP2 developed similarly with this difference that in all treatments its systematic decrease occurred, with the slowest, like in case of previous coefficient, in treatment TS2.

Coefficient WP3 was the most stable (Table 5). In first period, in majority of treatments a small decrease of this coefficient took place, remained constant on the same level in treatment TU2 and a vivid increase in treatments of heavy thinning - TS1 and TS2 - was noticed. However, in second period in treatment TS1 a drop of coefficient occurred, and a small increase was still noted in treatment TS2, and also in TG2 and K.

The analysis of WP 3 changes showed in the first period a very significant influence of cutting treatment (Table 6), and also group significant influence. Homogenous group of treatments of the biggest increase were treatments TS1, TS2 and TG2, wherein the first of them stands out most firmly (Fig. 1). Change of coefficient in treatment TU2 also had a positive value. In second period, reduction of coefficient value occurred in treatment TS1 and increase in treatments TG2, TS2 and K. In effect, in all 12 years, the treatment influence was very significant (Table 6) and positive coefficient's change occurred in treatments TS2, TG2 and TS1. The biggest decrease of coefficient's value was in treatment TG1. 
Table 5. Dominance coefficients (WP1, WP2 and WP3) of future crop trees depending on year and treatment in Kozienice experimental plot

\begin{tabular}{c|ccc|ccc|ccc}
\hline \multirow{2}{*}{ Treatment* } & \multicolumn{3}{|c|}{ WP1 } & \multicolumn{3}{c|}{ WP2 } & \multicolumn{3}{c}{ WP3 } \\
\cline { 2 - 10 } & 1999 & 2005 & 2011 & 1999 & 2005 & 2011 & 1999 & 2005 & 2011 \\
\hline K & 1.254 & 1.256 & 1.183 & 1.147 & 1.129 & 1.104 & 0.812 & 0.807 & 0.810 \\
\hline TG1 & 1.267 & 1.201 & 1.138 & 1.141 & 1.102 & 1.098 & 0.840 & 0.831 & 0.818 \\
\hline TG2 & 1.239 & 1.191 & 1.105 & 1.109 & 1.088 & 1.078 & 0.807 & 0.806 & 0.815 \\
\hline TS1 & 1.261 & 1.261 & 1.146 & 1.152 & 1.127 & 1.093 & 0.825 & 0.864 & 0.837 \\
\hline TS2 & 1.307 & 1.301 & 1.195 & 1.168 & 1.166 & 1.144 & 0.856 & 0.869 & 0.872 \\
\hline TU1 & 1.267 & 1.251 & 1.160 & 1.158 & 1.127 & 1.106 & 0.851 & 0.842 & 0.829 \\
\hline TU2 & 1.265 & 1.256 & 1.146 & 1.158 & 1.144 & 1.093 & 0.838 & 0.838 & 0.830 \\
\hline Average & 1.266 & 1.245 & 1.153 & 1.148 & 1.126 & 1.102 & 0.833 & 0.837 & 0.830 \\
\hline \hline
\end{tabular}

* As in Table 1

WP1 - relationship between dbh of given tree and mean dbh of stand

WP2 - relationship between dbh of given tree and mean dbh of dominant trees in stand

WP3 - relationship between dbh of given tree and mean dbh of 100 thickest trees per hectare

Figure 1. Change of WP3 coefficient in consecutive measurement periods and 7 treatments in Kozienice experimental plot

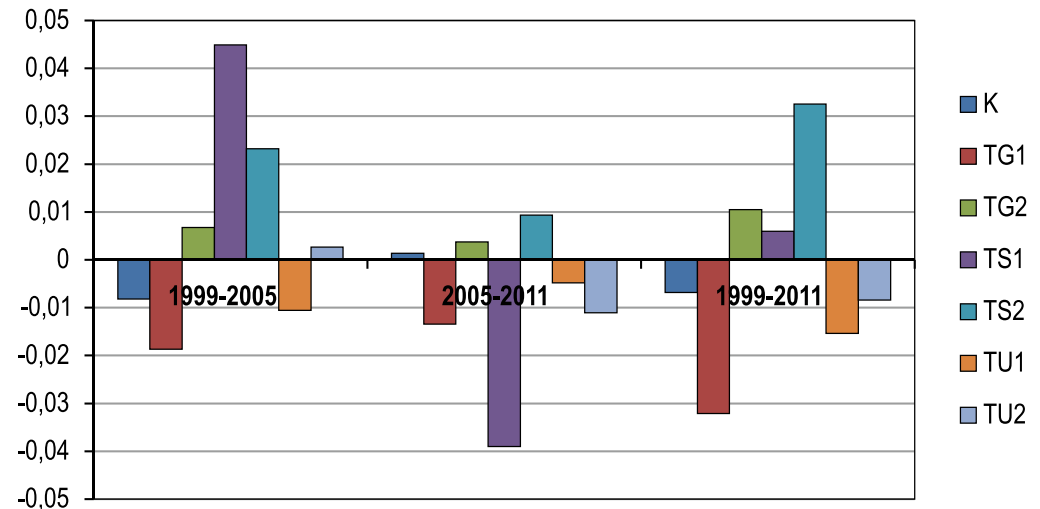

Table 6. ANOVA results of WP3 coefficient changes in 7 spacing-thinning treatments in Kozienice experimental plot

\begin{tabular}{|c|c|c|c|c|}
\hline Period & $\begin{array}{l}\text { Source of } \\
\text { variation }\end{array}$ & F statistics & $\begin{array}{c}\text { Significance } \\
\text { level }\end{array}$ & Homogenous groups \\
\hline \multirow[t]{5}{*}{ 1999-2005 } & A - treatment & 5.382 & 0.0000 & 1: TG1, TU1, K, TU2, TG2 \\
\hline & & & & 2: TU1, K, TU2, TG2, TS2 \\
\hline & & & & 3: TG2, TS2, TS1 \\
\hline & B - group* & 5.964 & 0.0031 & 1: $\mathrm{g}$ \\
\hline & & & & 2: s, c \\
\hline \multirow[t]{3}{*}{ 1999-2011 } & $\mathrm{A}$ - treatment & 3.707 & 0.0017 & 1: TG1, TU1, TU2, K, TS1, TG2 \\
\hline & & & & 2: TU2, K, TS1, TG2, TS2 \\
\hline & B - group & 1.374 & 0.2557 & - \\
\hline
\end{tabular}

* 3 groups of future crop trees with initial WP3 coefficient in partitions: $1-0.65-0.75 ; 2-0.75-0.85 ; 3-0.85-0.95$

Bolded numbers - significant effect 


\subsection{2. Łąck plot}

The value of WP1 coefficient in first period of measurements decreased in all treatments, except for treatment F (Table 7). In second period, i.e. to 2007, it increased in all treatments, except for TG2 and $\mathrm{K}$ treatment, and in third it decreased in every treatment. This may mean that in this period, displacement of largest group of trees of lower social classes occurred, increasing at the same time the average dbh of forest stand.

This coefficient in individual treatments was very similar in the beginning of experiment, and in period after first thinning, its increase occurred in all treatments, so that in the second period another reduction was noted. In 2012, all treatments (except for TU1) were characterised with higher WP2 coefficient than in the beginning of thinning experiment.

The value of WP3 coefficient slightly decreased in period after first thinning in all treatments, except for treatment with heavy thinning - TS1 and TS2; in second period it increased in all treatments, except for treatments TG2 and $\mathrm{K}$; in third it slightly decreased in all treatments (Table 7).

Analysis of WP3 coefficient changes showed a significant influence of cutting treatment in first period (Table 8). The largest drop of this coefficient was visible in K treatment (control) and the highest increase in treatment TS2 (Fig. 2). In the 15-year period, positive change of WP3 coefficient took place in treatments TU2, TS2, TU1 and TS1, while negative in treatments TG1, TG2 and K. These changes, however, are not proved statistically (Table 8). This may result in a harder to analyse statistically nonblock experiment system.

\subsubsection{Parciaki plot}

As was mentioned earlier, an intense disease process revealed itself in this plot, resulting in mass tree displacement.

Table 7. Dominance coefficients of future crop trees depending on year and treatment in Łąck experimental plot

\begin{tabular}{|c|c|c|c|c|c|c|c|c|c|c|c|c|}
\hline \multirow{2}{*}{ Treatment* } & \multicolumn{4}{|c|}{ WP1 } & \multicolumn{4}{|c|}{ WP2 } & \multicolumn{4}{|c|}{ WP3 } \\
\hline & 1997 & 2003 & 2007 & 2012 & 1997 & 2003 & 2007 & 2012 & 1997 & 2003 & 2007 & 2012 \\
\hline K & 1.229 & 1.203 & 1.192 & 1.173 & 1.068 & 1.126 & 1.087 & 1.095 & 0.815 & 0.806 & 0.802 & 0.793 \\
\hline TG1 & 1.312 & 1.227 & 1.238 & 1.167 & 1.100 & 1.149 & 1.119 & 1.103 & 0.835 & 0.831 & 0.833 & 0.822 \\
\hline TG2 & 1.260 & 1.200 & 1.195 & 1.161 & 1.079 & 1.130 & 1.110 & 1.100 & 0.832 & 0.822 & 0.818 & 0.808 \\
\hline TS1 & 1.264 & 1.250 & 1.261 & 1.209 & 1.103 & 1.153 & 1.131 & 1.123 & 0.853 & 0.853 & 0.856 & 0.849 \\
\hline TS2 & 1.291 & 1.309 & 1.318 & 1.249 & 1.115 & 1.198 & 1.170 & 1.163 & 0.851 & 0.866 & 0.867 & 0.860 \\
\hline TU1 & 1.290 & 1.223 & 1.228 & 1.153 & 1.107 & 1.134 & 1.116 & 1.096 & 0.821 & 0.808 & 0.814 & 0.810 \\
\hline TU2 & 1.236 & 1.212 & 1.217 & 1.180 & 1.096 & 1.148 & 1.111 & 1.099 & 0.830 & 0.827 & 0.831 & 0.827 \\
\hline Average & 1.269 & 1.232 & 1.236 & 1.185 & 1.095 & 1.148 & 1.121 & 1.111 & 0.834 & 0.830 & 0.832 & 0.824 \\
\hline
\end{tabular}

* As in Table 1

Figure 2. Change of WP3 coefficient in consecutive measurement periods in Łąck experimental plot

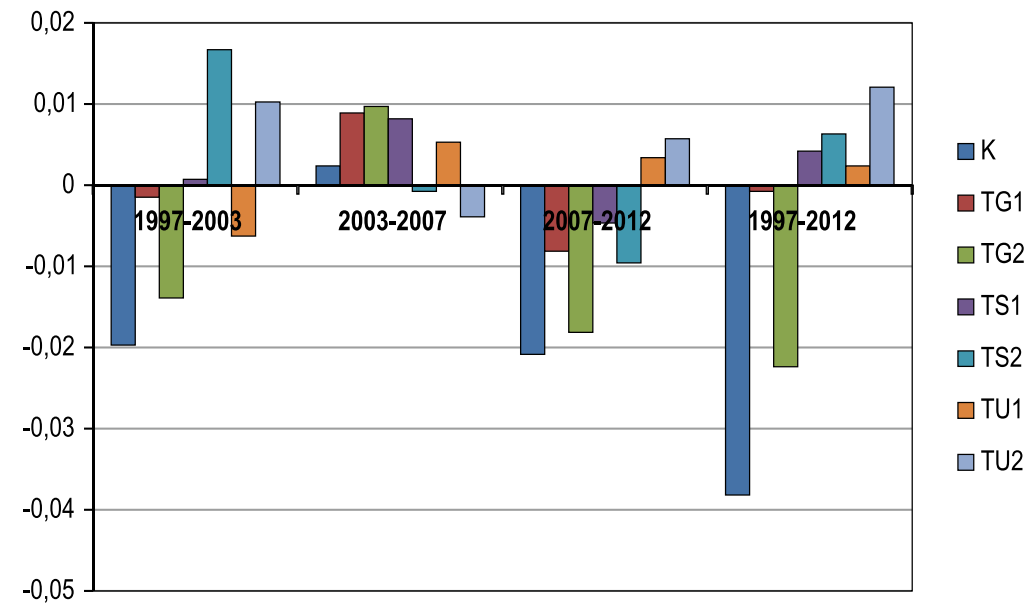


Table 8. ANOVA results of WP3 coefficient changes in 7 spacing-thinning treatments in Kozienice experimental plot

\begin{tabular}{clccc}
\hline \hline Period & Source of variation & F statistics & Significance level & Homogenous groups \\
\hline 1997-2003 & A - treatment & $\mathbf{3 . 2 0 1}$ & $\mathbf{0 . 0 0 5 1}$ & 1: K, TG2, TU1, TG1, TS1 \\
& & & & 2: TG2, TU1, TG1, TS1, TU2 \\
& & & & 3: TU1, TG1, TS1, TU2, TS2 \\
\cline { 2 - 5 } & B - group* & 0.381 & 0.6836 & - \\
\hline \multirow{2}{*}{$1997-2012$} & A - treatment & 1.809 & 0.0992 & - \\
\cline { 2 - 5 } & B - group & 2.102 & 0.1251 & - \\
\hline
\end{tabular}

* As in Table 6

Table 9. Dominance coefficients of future crop trees depending on year and treatment in Parciaki experimental plot

\begin{tabular}{|c|c|c|c|c|c|c|c|c|c|c|c|c|}
\hline \multirow{2}{*}{ Treatment* } & \multicolumn{4}{|c|}{ WP1 } & \multicolumn{4}{|c|}{ WP2 } & \multicolumn{4}{|c|}{ WP3 } \\
\hline & 1998 & 2003 & 2006 & 2012 & 1998 & 2003 & 2006 & 2012 & 1998 & 2003 & 2006 & 2012 \\
\hline $\mathrm{K}$ & 1.351 & 1.235 & 1.167 & 1.152 & 1.125 & 1.109 & 1.088 & 1.062 & 0.789 & 0.808 & 0.820 & 0.808 \\
\hline TG1 & 1.441 & 1.214 & 1.185 & 1.175 & 1.131 & 1.103 & 1.094 & 1.074 & 0.778 & 0.773 & 0.798 & 0.800 \\
\hline TG2 & 1.416 & 1.271 & 1.190 & 1.187 & 1.138 & 1.121 & 1.102 & 1.093 & 0.807 & 0.801 & 0.810 & 0.815 \\
\hline TS1 & 1.337 & 1.240 & 1.203 & 1.175 & 1.149 & 1.164 & 1.111 & 1.096 & 0.795 & 0.820 & 0.839 & 0.857 \\
\hline TS2 & 1.427 & 1.259 & 1.225 & 1.214 & 1.155 & 1.139 & 1.134 & 1.114 & 0.813 & 0.837 & 0.859 & 0.860 \\
\hline TU1 & 1.334 & 1.215 & 1.188 & 1.181 & 1.115 & 1.122 & 1.105 & 1.105 & 0.814 & 0.829 & 0.844 & 0.858 \\
\hline TU2 & 1.325 & 1.202 & 1.174 & 1.146 & 1.108 & 1.127 & 1.083 & 1.067 & 0.816 & 0.838 & 0.839 & 0.848 \\
\hline Average & 1.376 & 1.234 & 1.190 & 1.176 & 1.132 & 1.126 & 1.102 & 1.087 & 0.802 & 0.815 & 0.830 & 0.835 \\
\hline
\end{tabular}

* As in Table 1

Table 10. ANOVA results of WP3 coefficient changes in 7 spacing-thinning treatments in Parciaki experimental plot

\begin{tabular}{clccc}
\hline Period & Source of variation & F statistics & Significance level & Homogenous groups \\
\hline 1998-2003 & A - treatment & $\mathbf{5 . 1 7 9}$ & $\mathbf{0 . 0 0 0 1}$ & $\begin{array}{c}\text { 1: TG1, TG2, K } \\
\text { 2: TG2, K, TS1, TU1, TU2 } \\
\end{array}$ \\
& & & & 3: K, TS1, TU1, TU2, TS2 \\
\cline { 2 - 5 } & B - group* & 0.525 & 0.5925 & - \\
\hline \multirow{2}{*}{$1998-2012$} & A - treatment & $\mathbf{2 . 5 9 3}$ & $\mathbf{0 . 0 1 9 4}$ & - \\
\cline { 2 - 5 } & B - group & 0.884 & 0.4150 & - \\
\hline \hline
\end{tabular}

* As in Table 6

That is why the population of crop trees that survived a 14year research period is not great. The forest stand, unlike others, was not managed earlier; therefore, the initial levels of WP1 coefficient value are very high. This is caused by low average dbh forest stand, and significant reduction of coefficient in all treatments in the following years (Table 9).

In first period after thinning, the increase of WP2 coefficient occurred in treatments of moderate thinning TU1 and TU2 and in treatment of heavy thinning TS1 and reduction of this coefficient in remaining treatments. The difference in forest stand's reduction in two treatments of heavy thinning TS1 and TS2 may have resulted from the fact that in this last one, characterised by dense initial spacing, during thinning a large number of thin trees with high social position were removed, increasing average dbh of this class. In the following periods, smaller 
Figure 3. Change of WP3 coefficient in consecutive measurement periods in Parciaki experimental plot

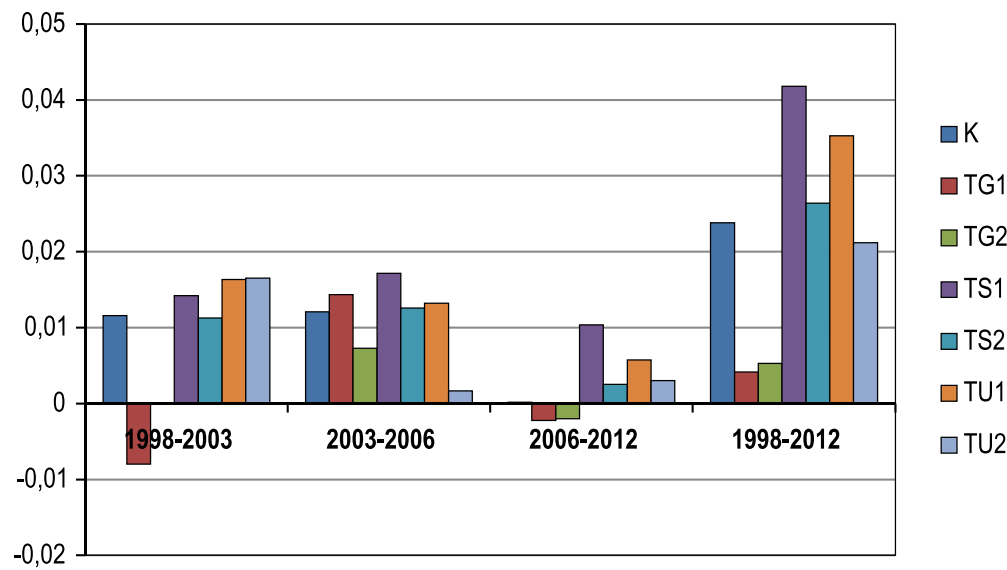

or greater coefficient decrease was noted, but due to very intensive loss it is hard to interpret these data.

WP3 coefficient increased in first period in all treatments, with the exception of group thinning treatments TG1 and TG2; however, in following periods, during intense loss duration, it increased in all treatments, including TG1 and TG2 (Table 9).

The variance analysis showed relevant influence of treatment on coefficient changes in first period (Table 10). Negative change occurred in treatment TG1, close to zero in treatment TG2 and positive in remaining treatments (Fig. 3). For the 14-year period, homogenous groups could not be distinguished (Table 10). In all of treatments, an increase of coefficient occurred, but in case of TG1 and TG2 treatments it was visibly smaller.

\subsubsection{Janów plot}

At the beginning of the experiment, the forest stand on this plot was younger than in others (compare Section 2.1); that is why the values of coefficient on the beginning

Table 11. Dominance coefficients of future crop trees depending on year and treatment in Janów Lubelski experimental plot

\begin{tabular}{cccccccccc}
\hline \hline Coefficient & Treatment* & 1976 & 1981 & 1986 & 1991 & 1996 & 2001 & 2007 & 2012 \\
\hline \multirow{5}{*}{ WP1 } & $\mathrm{K}$ & 1.383 & 1.309 & 1.254 & 1.165 & 1.088 & 1.089 & 1.058 & 1.046 \\
& $\mathrm{~S} 1$ & 1.421 & 1.297 & 1.236 & 1.177 & 1.123 & 1.124 & 1.098 & 1.064 \\
& $\mathrm{~S} 3$ & 1.359 & 1.249 & 1.209 & 1.139 & 1.095 & 1.101 & 1.068 & 1.050 \\
& $\mathrm{TE}$ & 1.362 & 1.044 & 1.056 & 1.057 & 1.042 & 1.058 & 1.024 & 1.025 \\
\cline { 2 - 9 } & average & 1.381 & 1.225 & 1.189 & 1.134 & 1.087 & 1.093 & 1.062 & 1.046 \\
\hline \multirow{5}{*}{ WP2 } & $\mathrm{K}$ & 1.088 & 1.062 & 1.059 & 1.045 & 0.989 & 0.991 & 0.988 & 0.981 \\
& $\mathrm{~S} 1$ & 1.104 & 1.072 & 1.064 & 1.064 & 1.012 & 1.009 & 1.027 & 1.021 \\
& $\mathrm{~S} 3$ & 1.095 & 1.088 & 1.081 & 1.073 & 1.023 & 1.022 & 1.027 & 1.021 \\
& $\mathrm{TE}$ & 1.088 & 1.011 & 1.023 & 1.016 & 0.998 & 1.021 & 1.012 & 1.004 \\
\hline \multirow{5}{*}{ WP3 } & average & 1.094 & 1.058 & 1.057 & 1.049 & 1.005 & 1.011 & 1.013 & 1.007 \\
\hline & $\mathrm{K}$ & 0.801 & 0.779 & 0.779 & 0.781 & 0.785 & 0.770 & 0.765 & 0.765 \\
& $\mathrm{~S} 1$ & 0.792 & 0.774 & 0.763 & 0.766 & 0.772 & 0.758 & 0.769 & 0.781 \\
& $\mathrm{~S} 3$ & 0.800 & 0.796 & 0.782 & 0.795 & 0.808 & 0.792 & 0.813 & 0.829 \\
& $\mathrm{TE}$ & 0.783 & 0.783 & 0.799 & 0.792 & 0.800 & 0.789 & 0.814 & 0.815 \\
\hline \hline
\end{tabular}

\footnotetext{
* As in Table 4
} 
Table 12. ANOVA results of WP3 coefficient changes in 4 spacing-thinning treatments in Janów experimental plot

\begin{tabular}{|c|c|c|c|c|}
\hline Period & Source of variation & F statistics & Significance level & Homogenous groups \\
\hline \multirow[t]{3}{*}{ 1976-1981 } & $\mathrm{A}-$ treatment & 3.589 & 0.0161 & 1: K, S1, S3 \\
\hline & & & & 2: S3, TE \\
\hline & B - group* & 1.431 & 0.2435 & - \\
\hline \multirow[t]{4}{*}{ 1976-1996 } & $\mathrm{A}-$ treatment & 7.850 & 0.0001 & 1: K, S1 \\
\hline & & & & 2: S1, S3 \\
\hline & & & & 3: S3, TE \\
\hline & B - group & 0.522 & 0.5949 & - \\
\hline \multirow[t]{3}{*}{ 1976-2012 } & $\mathrm{A}-$ treatment & 5.219 & 0.0021 & 1: K, S1, S3 \\
\hline & & & & 2: S3, TE \\
\hline & B - group & 1.994 & 0.1411 & - \\
\hline
\end{tabular}

* As in Table 1

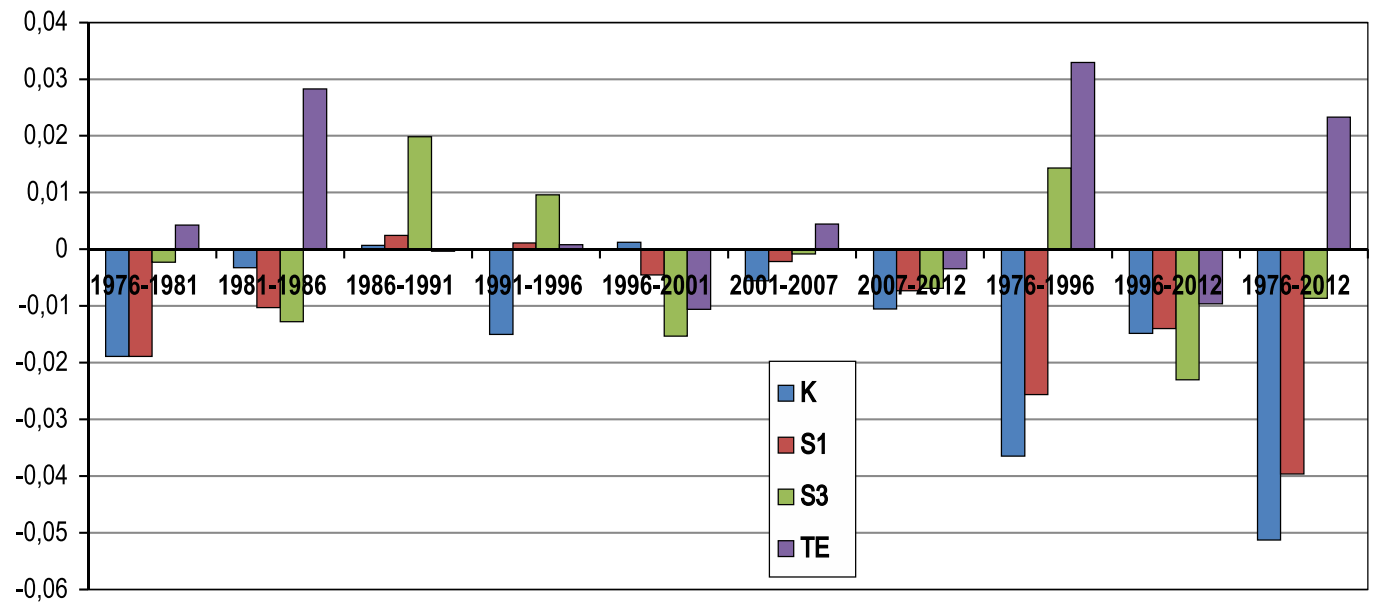

Figure 4. Change of WP3 coefficient in consecutive measurement periods in Janów experimental plot

of experiment were significantly higher (Table 11). After first thinning, these coefficients decreased in all of examined treatments. They decreased the most in extreme thinning TE treatment because that is where the average forest stands dbh increased the most. In the following research periods, slow decrease of coefficient value occurred, and after 1996 a one-time increase occurred. It may have been connected with (mentioned in Section 3.1) additional cutting performed in part of the plot.

The development of WP2 coefficient runs similar as in case of WP1 coefficient; however, those changes were not so rapid because average dbh of dominant class changes slower than average dbh of whole forest stand.
The greatest decrease of coefficient value took place in TE treatment, although in 1986 in this treatment an increase was also noted. In 2012, treatment K (control) was characterised with the lowest value of coefficient.

WP3 coefficient in research period underwent various changes depending on cutting treatment. In first period it decreased in all treatments, except for TE treatment (Table 11). In control treatment, it slowly, but systematically, decreased. In S1 and S3 treatments, it initially decreased, and then increased. In 2012, the coefficient had in S3 treatment the highest value. In TE treatment, it was slightly smaller, which can be explained by less frequent interventions running. 
Variance analysis showed a relevant influence of cutting treatment on WP3 coefficient change for first measurement period, for whole research period and for first 20 years of experiment (Table 12). The strongest influence stated was in case of II age class. It may be connected with the fact that heavy thinning gives a long-term effect; this is why the greatest coefficient increase in TE and S3 occurred not in the first 5-year period, but in next period (Fig. 4). In 1996-2012, the coefficient's decrease took place in all treatments. In II age class treatments TE and S3 were characterised with a positive coefficient change, and at the end of III age class only TE treatment.

\section{Summary and discussion}

The results obtained within presented research do not allow for drawing far reaching conclusions concerning the usefulness of the thinning method due to the fact that it was tested for limited scale and with various initial states (spacing experiment adaptation).

For evaluation of increment reaction, dominance coefficients were used as defined in earlier elaborations (Zachara 1998, 1999). Two of them were used earlier in forest experimenting. Ilmurzyński (1974) evaluated the accuracy of tree selections on the basis of dominance of a given tree's dbh over average dbh, which corresponds to WP1 coefficient defined in this thesis. Hynynen (1995) defined the reaction of a single tree for thinning with the use of its dbh to average dbh of 100 thickest trees per hectare ratio, that is, WP3 coefficient.

WP1 coefficient, as proved in earlier research in plots in Wyszków, Ostrów Mazowiecka and Myszyniec Forest Inspectorates (Zachara 1998), is very dependent on forest stand density degree, where rapid changes in following measurement periods result. In research from 1998 after first thinning performed around 20 years of age, greater decrease of WP1 coefficient characterised treatments of greater severity of cutting. Later, the situation reversed - in the following periods, the largest decrease occurred in control treatment. At the end of II age class, differences between cutting treatments could be noticed, when it comes to the coefficient value. Similar results obtained were in current research.

WP2 coefficient, on the other hand, was supposed to be a better version of WP1 coefficient, less dependent on social forest stand structure and occurrence of intermediate and suppressed trees. It should be noticed, however, that its value depends to a large extent on tree movement in biosocial classes. The regression of certain number of dominant trees to lower classes automatically causes the increase of average dbh of dominant forest stand, which can be expected in control treatment or in light thinning treatment. On the other hand, in managed forest stand, in comparison with control treatment, the increase of average dbh of tree from dominant layer should be expected (Pařez 1980). This is why the interpretation of this coefficient's changes may show certain difficulties. Additional complication is a subjective evaluation of trees' social position, which has an influence on the obtained result, especially when during the experiment the change of leading person occurs, which is inevitable with longterm experiments. Such change took place for example in Łąck plot, where different results than in other objects were obtained - coefficient increase in period after first thinning. Therefore, this coefficient should be treated only as indicative information, and not a precise measure of changes in forest stand.

The most interesting from cognitive point of view are results of analysis of WP3 coefficient changes, which is the most stable measure of tree growth situation changes. Earlier research (Zachara 1998) showed an important influence of cutting intensification on crop trees growth on the beginning of II age class, except for one plot established in poorer habitat (II bonitation) and gradual disappearance of differences in the following periods. Some authors even conclude that positive thinning effect in pine is possible only in richer habitats (Kojola et al. 2012).

Equally strong reaction relying on increase of WP3 coefficient was registered in present research on Kozienice, Łąck and Parciaki plots, especially in heavy thinning treatments according to crop trees. Again, in the following periods elimination of these differences occurred. The exception was Parciaki plot, in which a significant influence of cutting treatment on changes of WP3 coefficient was proved in all periods. It was caused doubtless by canopy opening of forest stand, which was a result of progressive disease. Trees, which avoided infection, gained therefore better growth conditions.

A slightly different situation was in Janów plot, where inter alia extreme thinning treatment was used, giving long-term density reduction. Here, the strongest reaction after thinning noted was in second 5-year period. The influence of cutting treatment was stronger in 20 -year period than in first 5 years. It may be interpreted as an effect of lower reaction of forest stand on weaker habitat (Ważyński 1987) because the fragments of plot are characterised by II bonitation.

In 20-year period, a relevance of heavy and extreme thinning influence was stated, and in 36-year period, counting from the beginning of experiment, only extreme 
thinning. Such results may be interpreted as an argument in favour of very heavy and rare thinning. However, this interpretation has some weaknesses - such heavy thinning performed was only on small 10 -acre plots. It is not known what the thinning effects would be on large plots when it comes to threats from biotic and abiotic factors. According to Zajączkowski (1991), damages from hurricane winds in $70 \mathrm{~s}$ and $80 \mathrm{~s}$ of the $20^{\text {th }}$ century took place in these regions, where earlier heavy and large-area thinning was performed. For caution in excessive increasing of thinning intensification speaks also situation observed on Parciaki plot. The use of heavy thinning on that plot activated a disease process in forest stand. It is not clear what would be the effect of mass use of this method on quality and wood mechanical properties (Peltola et al. 2007).

In some plots, the influence of initial thickness of crop tree on thinning effect was stated. Trees in which WP3 coefficient amounted around 0.7 showed positive reaction on performed cutting, which indicates that choice of crop trees is possible not only among thickest individuals, and in consequence a more intense quality selection is possible (Zimmerman 2010). Similar results obtained were in two experiments with heavy thinning in pine forest stands in Germany and Czech Republic, with a low number of crop trees estimating 200 individuals/ha (Abetz and Chroust 2004). As indicated by Chroust's research results (2001), this regularity (positive reaction of thinner trees for performed cutting) concerns only individuals from dominant layer (II Kraft's class), because searching for crop trees among co-dominant trees (from III Kraft's class) does not give a positive effect - even with heavy upper thinning their increase in thickness is not satisfying. Earlier, Ilmurzyński (1974) as a criterion of crop trees choice adopted dbh $20 \%$ bigger from average dbh for forest stand (which is $\mathrm{WP} 1 \geq 1.2$ ). In the light of obtained results, however, this criterion should be acknowledged as imprecise, and be guided by WP3 coefficient as being more objective.

In the 1990s, in Meklemburgia area, a quite similar thinning experiment in pine forest stands was created in which a different number of crop trees were selected (from 170 to 600 individuals/ha). Initial results confirmed the influence of heavy thinning substantially higher than in traditional selective thinning on increase of crop trees thickness under the condition that their number is not bigger than 200 units/ha (Mehl 2003).

When it comes to the meaning of results for forest practice, the experiment conducted allows for making certain cautious generalisations. Significant effect of thinning in Janów was obtained by heavy thinning (S3 and TE) and in remaining plots by thinning according to crop trees (TS1 and TS2). In some plots, a positive effect could be stated also in case of moderate thinning (TU1 and TU2). On the other hand, light thinning (S1 in Janów) did not give such an effect. The same concerns group thinning (TG1 and TG2) in Kozienice, Łąck and Parciaki plots. In this last case, the cause may be the fact that one of the main goals of this thinning methods is to provide forest stand's stability (Zajączkowski 1990), which is connected also with avoiding forest stand's closure interruption.

\section{Conclusions}

Dominance coefficient WP3 is a good measure that allows assessing the usefulness of a given tree for a crop tree and for evaluating thinning effects. At heavy thinning, crop trees chosen may be those of coefficient WP3 $\geq 0.7$.

Permanent thinning effect, which is an improvement of crop trees growth in comparison with the rest of forest stand, may be obtained under influence of heavy or moderate thinning. Light thinning does not give such an effect.

The basic method of Scots pine forest stands thinning should remain moderate selective thinning. The use of strong cutting in favour of smaller number of crop trees may be used for experimental purposes in objects characterised by a good sanitary condition and managed properly.

\section{Acknowledgements}

This research received no specific grant from any funding agency in the public, commercial or not-forprofit sectors.

\section{References}

Abetz P. 1967. Erste Ergebnisse aus Stammzahlreduzierungsversuchen in Fichten- und Kiefernjungbeständen. $A F Z, 33$ : 565-568.

Abetz P. 1976. Beiträge zum Baumwachstum. Der h/d-Wertmehr als ein Schlankheitsgrad. Der Forst- und Holzwirt, 19: 389-393.

Abetz P., Chroust 2004. Wachstumvergleiche in zwei Kiefern-Durchforstungsversuchen in Tschechien und Deutschland. Allgemeine Forst und Jagdzeitung, 6: 117-124.

Alam A., Kilpeläinen A., Kellomäki S. 2012. Impacts of initial density and thinning regimes on energy wood production and management-related $\mathrm{CO}_{2}$ emissions in boreal ecosystems. European Journal of Forest Research, 131, 3: 655-667.

Bernadzki E. 1969. Zmiany wartości hodowlanej drzewostanu pod wpływem cięć liniowych [Alterations in the silvicultural value of stand due to line thinning]. Sylwan, 10: 1-10.

Bernadzki E., Ilmurzyński E., Szymański S. 1999. Trzebieże. Poradnik leśniczego. Warszawa, PWRiL. 
Chroust L. 2001. Výsledky úrovňové a podúrovňové výchovy borového porostu. Lesnická Práce, 6: 252-254.

Fries J. 1969. Der Einfluss extrem starker Durchforstung auf den Ertrag und die Bestandessicherheit von Nadelholzbeständen. $A F Z, 39$ : 760-761.

Grynkiewicz J 1972. Wpływ trzebieży selekcyjnej i cięć liniowych na powstawanie szkód śniegowych w drzewostanach sosnowych [The influence of selection thinning and row removal upon the occurrence of snow-induced damage in pine stands]. Sylwan, 3: 17-28.

Grynkiewicz J. 1988. Próba weryfikacji biologiczno-hodowlanych klas drzew wyróżnionych w drzewostanach sosnowych II klasy wieku. Prace Instytutu Badawczego Leśnictwa, 661: 94-129.

Huss J. 1983. Durchforstungen in Kiefernjungbeständen. Forstwissen-schaftliches Centralblatt, 1: 1-17.

Huss J. 1993. Waldbau von neuen Herausforderungen bei Waldverjüngung und Jungbestandspflege. Forstwissen-schaftliches Centralblatt, 3: 278-286.

Hynynen J. 1995. Predicting the growth response to thinning for Scots pine stands using individual-tree growth models. Silva Fennica, 29 (3), 225-246.

Ilmurzyński E. 1974. Badania nad trafnością wyboru drzew dorodnych w drzewostanach sosnowych, dębowych i bukowych. Prace Instytutu Badawczego Leśnictwa, 470: 1-50.

Johann K. 1981. Nicht schnee, sondern falsche Bestandesbehandlung verursacht Katastrophen. Allgemeine Forstzeitung, 92 (5): 163-171.

Kojola S., Ahtikoski A., Hökkä H., Penttilä 2012. Profitability of alternative management regimes in Scots pine stands on drained peatlands. European Journal of Forest Research, 131: 413-426.

Konôpka J., Petráš R., Toma R. 1987. Štíhlostný koeficient hlavných drevín a jeho význam pri statickej stabilite porastov. Lesnictvi, 33 (10): 887-904.

Leibundgut H. 1972. Pielęgnowanie drzewostanów. Warszawa, PWRiL, p. 160.

Mehl M. 2003. Erste Ergebnisse zur Z-Baumorientierten Auslesedurchforstung in Kiefernjungbeständen. Forstliches Versuchswesen $M-V, 4: 65-70$.

Pařez J. 1980. Fytocenotické postavení stromů v borovych tyčovinách a jeho změny. Lesnictvi, 1: 21-34.

Peltola H., Kellomäki S., Hassinen A., Lemettinen M., Aho J. 1993. Swaying of trees as caused by wind: analysis of field measurements. Silva Fennica, 27, 2: 113-126.

Peltola H., Kellomäki S., Hassinen A., Granander M. 2000. Mechanical stability of Scots pine, Norway spruce and birch: an analysis of tree-pulling experiments in Finland. Forest Ecology and Management, 135: 143-153.

Peltola H., Kilpeläinen A., Sauvala K., Räisänen T., Ikonen V.-P. 2007. Effects of early thinning regime and tree status on the radial growth and wood density of Scots pine. Silva Fennica, 3. 489-505.

Routa J., Kellomäki S., Peltola H., Asikainen A. 2011. Impacts of thinning and fertilization on timber production in Norway spruce and Scots pine: scenario analyses based on ecosystem model simulations. Forestry, 2: 159-171.

Schädelin W. 1942. Die Auslesedurchforstung als Erziehungsbetrieb höchster Wertleistung. Wyd. 3, Bern-Leipzig.

Slodičak M. 1995. Thinning regime in stands of Norway spruce subjected to snow and wind damage. In: Coutts M. P., Grace I. (eds). Wind and trees. Cambridge University Press: 436-447.

Stępień E. 1986. Zwiększanie stabilności drzewostanów przy pracach odnowieniowych. Sylwan, 1: 13-21.

Talkkari A., Peltola H., Kellomäki S., Strindman H. 2000. Integration of component models from the tree, stand and regional levels to assess the risk of wind damage at forest margins. Forest Ecology and Management, 135: 303-313.

Ważyński P. 1987. Produkcyjność pielęgnowanych i niepielęgnowanych drzewostanów sosnowych II klasy wieku. Prace Komisji Nauk Rolniczych i Komisji Nauk Leśnych PTPN, 64: 151-157.

Zachara T. 1998. Wpływ trzebieży selekcyjnej na strukturę socjalną i jakość hodowlaną drzewostanów sosnowych II klasy wieku. Praca doktorska. Instytut Badawczy Leśnictwa, Warszawa, p. 79.

Zachara T. 1999. Influence of selective thinning on growth of future crop trees population in young Scots pine stands. Folia Forestalia Polonica, Series A, 41: 87-103.

Zachara T. 2000. Wpływ trzebieży selekcyjnej na strukturę biosocjalną drzewostanu sosnowego w II klasie wieku [The influence of selective thinning on the social structure of the young Scots pine stand]. Prace Instytutu Badawczego Leśnictwa, 3 (902): 35-61.

Zajączkowski J. 1990. Stabilisieriende Gruppendurchforstung in Kiefernbeständen. Forstarchiv, 1: 39-40.

Zajączkowski J., 1991. Odporność lasu na szkodliwe działanie wiatru i śniegu. Warszawa, Wydawnictwo Świat. p. 224.

Zajączkowski J. 1994. Biogrupy drzew w drzewostanach możliwości i celowość ich wykorzystania przy prowadzeniu trzebieży. Prace Instytutu Badawczego Leśnictwa, Seria A, 778: 1-38.

Zimmerman R. 2010. Kiefern-Durchforstungsversuch „Spitze 314 a 1". AFZ Wald, 1: 26-29. 